\title{
Nanotechnologies in agricultural engineering: practice and prospects
}

\author{
Mukhtar Kerimov ${ }^{1}$, Viktor Smelik ${ }^{1}$, Movsar Kerimov ${ }^{3}$, Mikhail Volkhonov ${ }^{4,}$ and Viktor \\ Kukhar $^{5}$ \\ ${ }^{1}$ Saint Petersburg State Agrarian University, Petersburg highway 2, 196601 Saint Petersburg, Pushkin, \\ Russia \\ ${ }^{3}$ Saint Petersburg State Electrotechnical University "LETI", st. Professor Popov 5, 197376, Saint \\ Petersburg, Russia \\ ${ }^{4}$ Kostroma State Agricultural Academy, Kostroma Region, Kostroma District, 156530 Karavaevo, \\ Russia \\ ${ }^{5}$ Ural State Agrarian University, Russia
}

\begin{abstract}
The use of powdered concentrates increases the digestibility of feed components by the animal body. The biological activity of organic products increases due to the intensification of the process of useful substances extraction from them. The scientific basis for the formation of nanotechnologies is system effects, as well as features of physical, mechanical and biochemical phenomena that occur in powdered materials at the atomic and molecular levels and provide a synergistic effect. Using modern analytical tools in the field of nanoparticle research, a method for conducting search experiments has been developed, which provides for the possibility of studying the transformations occurring in the deep layers of substances and trace elements. Fine fractions participate in the formation of the structure of the final product, act as its leavening agents and sweeteners, as well as absorbers of excess moisture contained in raw materials. Hypersonic grinding using quantum aerogravity technology has shown the applicability, scientific and technical significance and prospects of this direction in the development of the powder industry.
\end{abstract}

\section{Introduction}

The powder industry is understood as a separate field of science and production that studies and practically develops crushed particles, changes in their properties and characteristics at the atomic and molecular level. The convergent technology adapted and implemented in agrobiological and technical applications is considered as its conceptual basis (Kovalchuk M.V., 2020). The creation and development of the powder industry corresponds to the state policy implemented in various countries aimed at improving the well-being of the population and, above all, solving the problem of food security. The strategy of creating a more dynamic economy provides for increasing labor productivity in the agro-industrial

\footnotetext{
${ }^{*}$ Corresponding author: martan-rs@yandex.ru
} 
complex, deep processing of organic raw materials, implementation of energy-and resourcesaving technological processes, and improving the quality of the final product.

The main trends in the agro-industrial complex are the consolidation of production and digitalization of the industry. In Russia and a number of European countries, the consumer market is slowing down, while the export potential is limited. Under these conditions, the feed industry inevitably undergoes stages of consolidation, mergers and acquisitions. In dairy cattle breeding, there are breakthrough processes for the active development of robotic technologies and precision animal husbandry tools. The trend of introducing artificial intelligence both in large livestock complexes and in the sphere of small bussinesses will increase [1].

Digitalization of agricultural production forms transparency as the basis of market relations. It provides for transparency not only in the composition and origin of feed, but also in the pricing system. Therefore, those market participants who adapt to new economic realities faster will have competitive advantages. Thus, monoproducts based on a singlecomponent raw material base will have an advantage over mixtures in the absence of accurate and stable laboratory data on the composition and recipe. The advantage will be given to market players who adapt to a fundamentally new competitive environment earlier than others.

The Ministry of Agriculture of the Russian Federation has developed a subprogram "Development of production of animal feed and feed additives" within the framework of the Federal Scientific and Technical Program for Agricultural Development for 2017-2025. It is aimed at creating the necessary feed ration for animals through the use of innovative technologies in the production of feed, vitamins, amino acids, and mineral supplements.

\section{Object of study and methodology}

The technology for producing fine powders is based on the separation of loaded organic raw materials, followed by its grinding due to the formation of two circular counter flows $[2,3,4]$. The movement of material in the flow occurs at a speed of $400 \ldots 700 \mathrm{~m} / \mathrm{s}$. The high speed of acceleration of material flows in a closed space contributes to the mechanical opening of capillaries of solid particles of the crushed product. This process is accompanied by evaporation of the smallest water particles released from the capillaries. Water in the form of a shell of a vapor-air mixture protects each particle from the influence of a thermal agent. This effect significantly affects the increase in plant productivity and the quality of the resulting products [5]. The process of powder production in the form of a flowchart is shown in Fig. 1. 


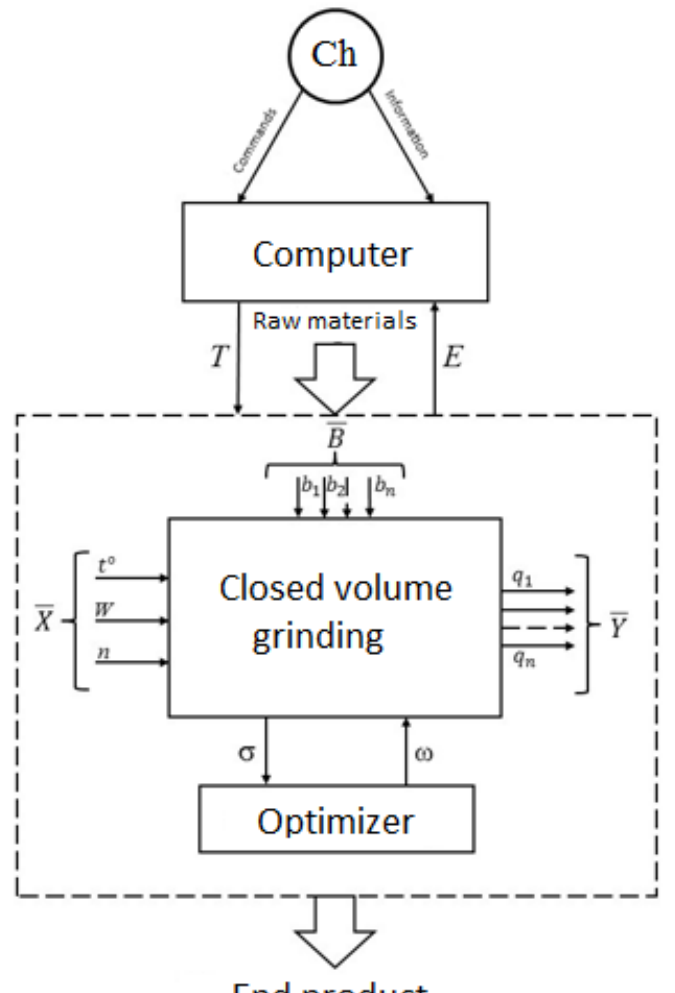

End product

Fig. 1. The flow-chart of technological process of powder production.

The scheme uses symbols:

$\mathrm{Ch}$ - operator; $\mathrm{T}$ - technological requirements for the process of raw materials grinding; E-generalized indicator of technological process efficiency; $\bar{X}$ - vector function of controlled parameters; $\bar{B}$ - vector function of unmanaged parameters; $\bar{Y}$ - vector function of output parameters.

The function $\overline{\mathrm{X}}_{\text {parameters are }} \mathrm{t}_{\mathrm{oc}}^{\mathrm{o}}$ - outdoor temperature $\left({ }^{\circ} \mathrm{C}\right) ; \mathrm{W}_{\mathrm{oc}}$ - raw material humidity, $\% ; n$-drum rotation speed, $\min ^{-1}$.

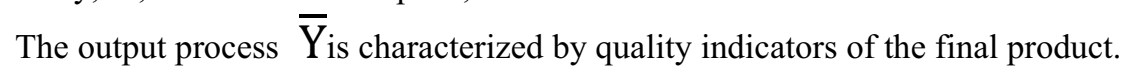

The optimizer is a software package that performs operational control of the quality of the shredder functioning according to the degree of dispersion of the material of the resulting material $\sigma$. It sends a control signal to the system in the form of $\omega$ (drums rotation speed) in cases when the values of $\sigma$ exceed the limits of the established technological tolerance.

The main indicators of technology efficiency are $[3,6,7]$ :

- low cost of raw materials;

- use of high-tech equipment in the production line;

- high level of profitability of production, reduction of energy intensity based on the use of combined aerodynamic drying processes;

- improved design of the disintegrator type shredder.

One of the important factors of the technology's implementation prospects in production is the ease of its integration into automated production lines. The distinctive features of using 
this grinding technology include [8,9]:

- climatic stability of the installation structure, its vibration resistance, possibility of frameless installation;

- compact and light weight design, ability to remote control and work in the field;

- fast technical transition from one product type to another;

- low maintenance costs combined with high specific productivity per unit of space occupied and electricity consumed;

- modular design of equipment in combination with a variety of layout solutions;

- low labor intensity in carrying out technical regulations;

- adaptability to explosive production processes;

- grinding in an ionized electromagnetic field, in the ultrasonic range.

During production tests of equipment and laboratory studies of substance samples, a wide range of applications of grinding technology and the use of powdered concentrates was established. Within the framework of agrobiological and technical applications, it is necessary to note two directions of technology implementation $[10,11]$ :

- feed additives for cattle, poultry;

- mineral fertilizers.

\section{Research results}

\subsection{The functioning and potential of technology in the field of fodder base}

In the subject area the authors have developed the technology and produced fodder additive "Kedrokorm". This is a complex of additional nutrition from the shell of a pine nut, which is a finely ground substrate for agricultural and domestic animals and birds. Recommendations for its use in compound feeds were compiled by scientists of the Saint Petersburg State Agrarian University [3].

Table 1. Results of application of feed additive Kedrokorm

\begin{tabular}{|c|c|c|c|}
\hline Object & \begin{tabular}{|l} 
Period \\
usageldose
\end{tabular} & Intermediate result & Control result \\
\hline Calves & $\begin{array}{l}\text { From } 10 \text { days } \backslash 100 \mathrm{mg} \\
\text { per } 1 \mathrm{~kg} \text { of live weight } \\
\text { per day. }\end{array}$ & $\begin{array}{l}\text { Restoration of GI } \\
\text { function - } \\
\text { gastrointestinal tract; } \\
\text { Reduction of } \\
\text { recovery time } \\
\text { sick calves for 2-3 } \\
\text { days }\end{array}$ & $\begin{array}{l}\text { activation of mobility, improvement of } \\
\text { growth and development; } \\
\text { effectiveness of the supplement for } \\
\text { gastrointestinal diseases of newborn calves } \\
\text { with a symptom complex of diarrhea was } \\
90.0 \% \text {, against } 60.0-80.0 \% \text { in comparison } \\
\text { with known agents (pectosorbin, antidiarin), } \\
\text { also } \\
\text { plant origin. }\end{array}$ \\
\hline Chicks & $\begin{array}{l}\text { From } 10 \text { days } \backslash 100 \mathrm{mg} \\
\text { per } 1 \mathrm{~kg} \text { of live weight } \\
\text { per day }\end{array}$ & $\begin{array}{l}\text { prevented } \\
\text { gastrointestinal } \\
\text { diseases }\end{array}$ & $\begin{array}{l}\text { normalized metabolic processes, } \\
\text { accelerated their growth and } \\
\text { development up to } 7 \% \text { compared to the } \\
\text { control group }\end{array}$ \\
\hline Cows & $\begin{array}{l}\text { From } 10 \text { days } \backslash 100 \mathrm{mg} \\
\text { per } 1 \mathrm{~kg} \text { of live weight } \\
\text { per day }\end{array}$ & & $\begin{array}{l}\text { increased the daily milk yield to } 1.5 \text { liters } \\
\text { and fat content, and also improved its } \\
\text { quality }\end{array}$ \\
\hline Chickens & $\begin{array}{l}\text { From } 10 \text { days } \backslash 200 \mathrm{mg} \\
\text { per } 1 \mathrm{~kg} \text { of live weight } \\
\text { per day }\end{array}$ & & $\begin{array}{l}\text { positively influenced the bird, egg } \\
\text { weight increased by } 8.0 \% \text {, and shell } \\
\text { thickness by } 7.9 \% \text {. }\end{array}$ \\
\hline
\end{tabular}


According to the results of laboratory research, the main composition of the supplement is formed by the content of carbohydrates (54\% - dietary fiber) and proteins, and in terms of macronutrients it is provided by the presence of potassium and phosphorus. At the same time, potassium takes part in all vital processes occurring in the body, and phosphorus participates in the process of preserving genetic information and contributes to the assimilation of other micro- and macronutrients, as well as vitamins. Due to the presence of phosphorus, which is not synthesized by the body, it is possible to form various components, such as proteins and carbohydrates, as well as to regulate the level of glucose production and absorption. Phosphorus is an element that forms the basis for the bones of the animal skeleton and contributes to the preservation of the acid-base balance of the body.

Table 2. Nutritional and energy value of the product Kedrokorm (in $100 \mathrm{~g}$ )

\begin{tabular}{|c|c|}
\hline Calorific value, kcal & 225 \\
\hline Protein, $\mathrm{g}$ & 20.3 \\
\hline Fat, $\mathrm{g}$ & 2.1 \\
\hline Carbohydrates, $\mathrm{g}$ & 68.4 , including hemicellulose (dietary fiber) -37.2 \\
\hline & Micro - and macro-elements: \\
\hline Potassium & $670.0 \mathrm{mg}$ \\
\hline Phosphorus & $300.0 \mathrm{mg}$ \\
\hline Manganese & $2700.0 \mathrm{mcg}$ \\
\hline Copper & $900.0 \mathrm{mcg}$ \\
\hline Zinc & $6800.0 \mathrm{mcg}$ \\
\hline Sodium & $10.0 \mathrm{mg}$ \\
\hline Iron & $4.29 \mathrm{mg}$ \\
\hline
\end{tabular}

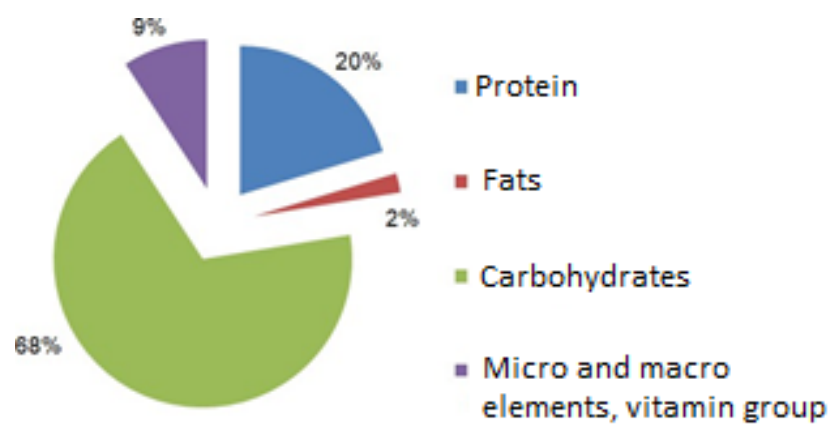

Fig. 2. Composition of Kedrokorm 


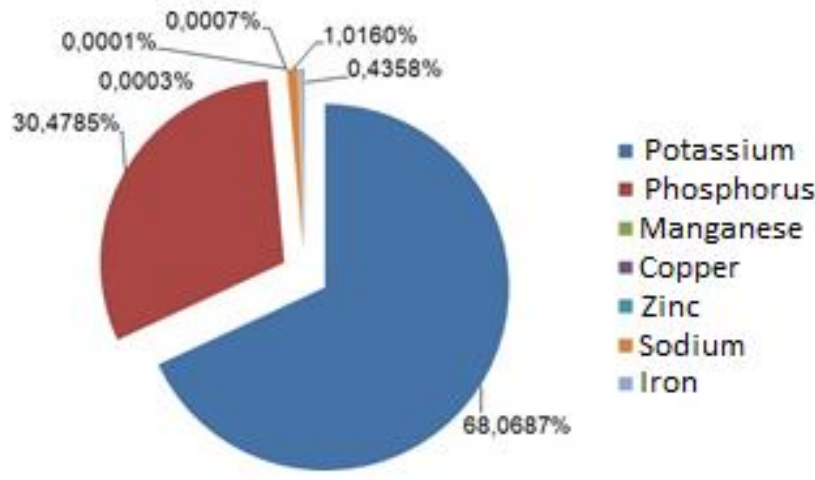

Fig. 3. Composition of micro- and macroelements of Kedrokorm

Based on the conducted research, the following results were obtained:

- primary and secondary immune deficiencies (local and systemic);

- maintenance and restoration of microflora during the period of medications intake and after it;

- prevention and reduction of harmful effects from stress in animals associated with transfer to another technological group, etc.;

- allergic diseases of various origins.

The sorption capacity of the additive is $29.6 \mathrm{mg}$ of methylene blue, which corresponds to the level of quality requirements for the preparation "Polyphepan".

Feeding of Kedrokorm helped to normalize energy, protein, lipid, carbohydrate and mineral metabolism, accelerate the recovery of sick animals and birds. However, no contraindications were detected during the entire testing period.

\subsection{Fertilizer potential}

The production of mineral fertilizers is an export-oriented branch of Russian industry. Fertilizer supplies to the domestic market in 2019 accounted for about $25 \%$ of the total amount of this type of product produced in the country. The rest is delivered to 119 countries, with Latin America being the largest consumer. In the first half of 2020, the supply of mineral fertilizers was increased by $35 \%$ to domestic agricultural producers.
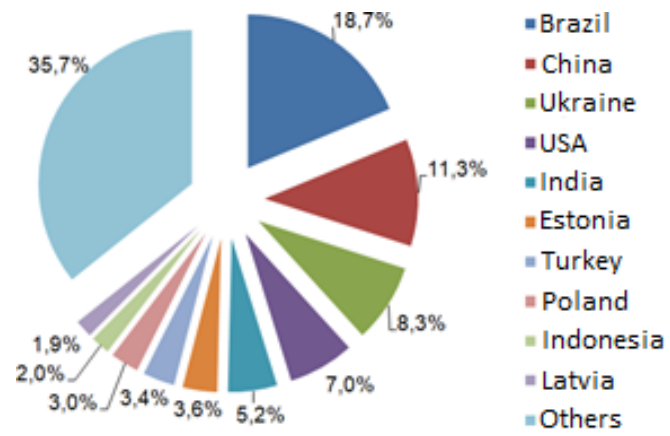

Fig. 4. Major buyers of Russian mineral fertilizers

Meanwhile, the Russian domestic market traditionally has its own contradictions. On a 
large territory of our country, arable land has a negative balance of humus, and scientific crop rotations are not observed everywhere. Therefore, domestic farmers should have priority in providing mineral fertilizers. This will ensure the guaranteed stability of the country's agroindustrial complex and preserve Russia's food security.

In recent years, there has been a decrease in the payback of mineral fertilizers as a resource. This is due to a reduction in the volume of work carried out under chemical land reclamation programs. At the same time, an important factor is the return of food elements to the biological cycle when selling grain, etc. At the same time, the Russian Federation has the largest reserves of peat in the world, and today peat is both the basis for restoring soil fertility and an innovative component of agricultural production. In addition, the use of peat should be considered as a source of heat and energy, as well as a factor for improving and protecting the environment.

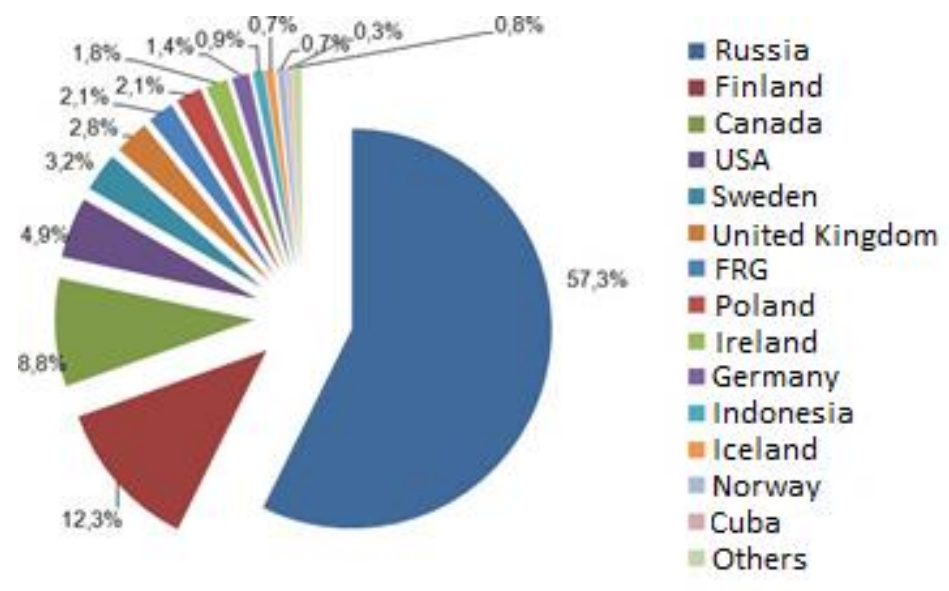

Fig. 5. Distribution of global peat reserves

Taking into account the availability of raw materials and the volume of the raw material base, this direction has prospects in the field of top peat processing into fertilizers for local use, so that logistics and transportation costs do not increase processing costs as a whole. The Peat Institute (Russia) conducted research on the content of protein, amino acids, micro- and macro-elements in its powder concentrate. Acids in the composition of top peat have antiseptic properties and good filtration, humic compounds are present in sufficient quantities, which are used as a natural filter against soil contamination with heavy metals and radionuclides. The demand for peat as a fertilizer is largely due to the high content of humus substances in it, which account for $20 \ldots 70 \%$ of the total mass.

Table 3. Composition of peat organic matter, \% of total organic matter

\begin{tabular}{|c|c|c|c|c|c|c|c|}
\hline \multirow[t]{2}{*}{ Peat type } & \multirow{2}{*}{$\begin{array}{l}\text { Depth, } \\
\text { cm }\end{array}$} & \multirow[t]{2}{*}{ Bitumens } & \multirow{2}{*}{$\begin{array}{c}\text { Water- } \\
\text { soluble } \\
\text { substances }\end{array}$} & \multirow{2}{*}{$\begin{array}{l}\text { Humus } \\
\text { substances }\end{array}$} & \multicolumn{2}{|c|}{$\begin{array}{c}\text { Hydrolyzable } \\
\mathrm{H}_{2} \mathrm{SO}_{4}\end{array}$} & \multirow{2}{*}{$\begin{array}{c}\text { Non- } \\
\text { hydrolyzable } \\
\text { residue }\end{array}$} \\
\hline & & & & & $1.0 \mathrm{~N}$ & $80 \%$ & \\
\hline \multirow{2}{*}{ Top } & $0-8$ & 2.6 & 3.1 & 12.1 & 15.6 & 34.7 & 32.4 \\
\hline & $8-40$ & 3.0 & 1.55 & 16.6 & 12.9 & 35.5 & 31.6 \\
\hline \multirow{2}{*}{$\begin{array}{c}\text { Low- } \\
\text { lying }\end{array}$} & $0-3$ & 2.9 & 5.5 & 34.5 & 7.4 & 16.3 & 32.3 \\
\hline & $10-60$ & 0.7 & 1.6 & 57.2 & 4.7 & 6.6 & 26.6 \\
\hline $\begin{array}{l}\text { Cattle } \\
\text { manure }\end{array}$ & - & 2.3 & - & 43.4 & 7.6 & 16.4 & 30.3 \\
\hline
\end{tabular}

Peat soils are among the most potentially fertile. They consist of $80-90 \%$ of organic matter, while in chernozems the humus content is 6-8 \%, in podzolic soils $1.5-2.5 \%$. 
Resource-saving integrated use of peat deserves attention and is an integral part of environmental management measures. The use of technology for grinding the upper layers of peat provides additional positive effects when fertilizing the fertile layer.

Currently, research is being conducted in this subject area, but on the example of additives from cedar nutshells and buckwheat sifting processed using hypersonic grinding technology, an increase in useful substances in comparison with the initial raw materials is established; for the most part, it is several times higher. Comparative analysis of the trace element composition of buckwheat was carried out by the FSUE "Russian Scientific Center "Applied Chemistry" and the testing laboratory of the St. Petersburg State Chemical and Pharmaceutical Academy.

Table 4. Comparative analysis of ordinary buckwheat flour and powder concentrate produced using the proposed grinding technology

\begin{tabular}{|l|c|c|c|}
\hline Content & Buckwheat flour & $\begin{array}{c}\text { Buckwheat powder } \\
\text { concentrate }\end{array}$ & Difference, \% \\
\hline Protein & 10 & 20.3 & $103 \%$ \\
\hline Potassium, mg $\backslash 100 \mathrm{~g}$ & 205 & 670 & $227 \%$ \\
\hline Sodium, mg $\backslash 100 \mathrm{~g}$ & 15 & 10 & $-33 \%$ \\
\hline Manganese, $\mathrm{mcg} \backslash 100 \mathrm{~g}$ & 760 & 2700 & $255 \%$ \\
\hline Copper, mcg $\backslash 100 \mathrm{~g}$ & 370 & 900 & $143 \%$ \\
\hline Zinc, mcg $\backslash 100 \mathrm{~g}$ & 1090 & 6800 & $524 \%$ \\
\hline Phosphorus, $\mathrm{mcg} \backslash 100 \mathrm{~g}$ & 343 & 300 & $-13 \%$ \\
\hline Iron, mg $\backslash 100 \mathrm{~g}$ & 1.8 & 4.29 & $138 \%$ \\
\hline
\end{tabular}

On the example of a cedar nutshell, it can be noted that gardeners use it as a mulch even if it is not processed. The use of cedar nutshells is justified by the fact that it prevents the growth of weeds, protects the soil from dehydration, erosion, salinization, and deep freezing. Cedar nutshells are effective against fungi and harmful insects. Phytoncides and flavonoids contained in the cedar substance create a bactericidal barrier around plants. Prepared according to this scheme, substrate has a favorable effect on the formation of microflora in the root environment, as evidenced by the appearance of earthworms in the soil.

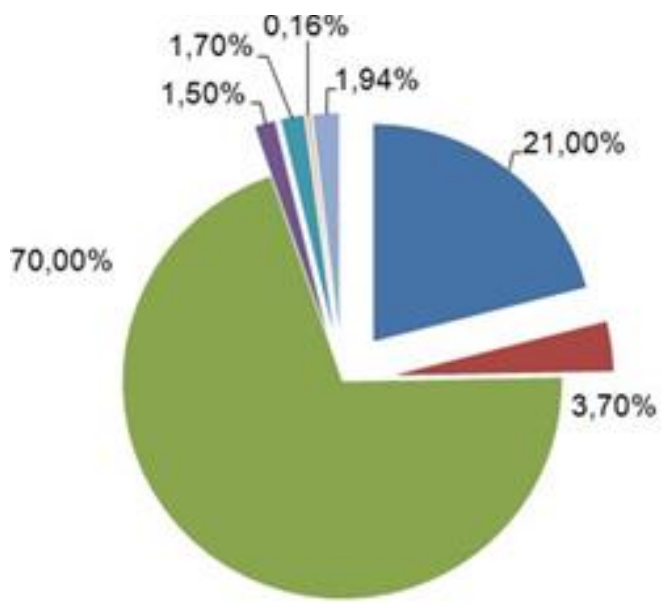

Tannins, pentosans

- Tin, vanadium, barium, ash, resins, amino acids, incl. glutamic acid

- Fiber

Protein

Fats

Macro- and microelements

Fig. 6. Composition of the whole cedar nutshell 
Cedar nutshell is a valuable raw material with its mineral composition. It includes such macro- and microelements as calcium, potassium, iron, manganese, etc. (table 4). The use of powdered concentrate from the cedar nuts shell as additives to fertilizers leads to a reduction of dangerous microorganisms, reducing post-harvest losses of products by reducing its spoilage.

In the research laboratory of the St. Petersburg State Chemical and Pharmaceutical Academy, the results of comparing the composition of powder from cedar nutshells using the developed grinding technology and unprocessed (ground) shells were obtained.

Table 5. Comparative analysis of the chemical composition of powder and small shell

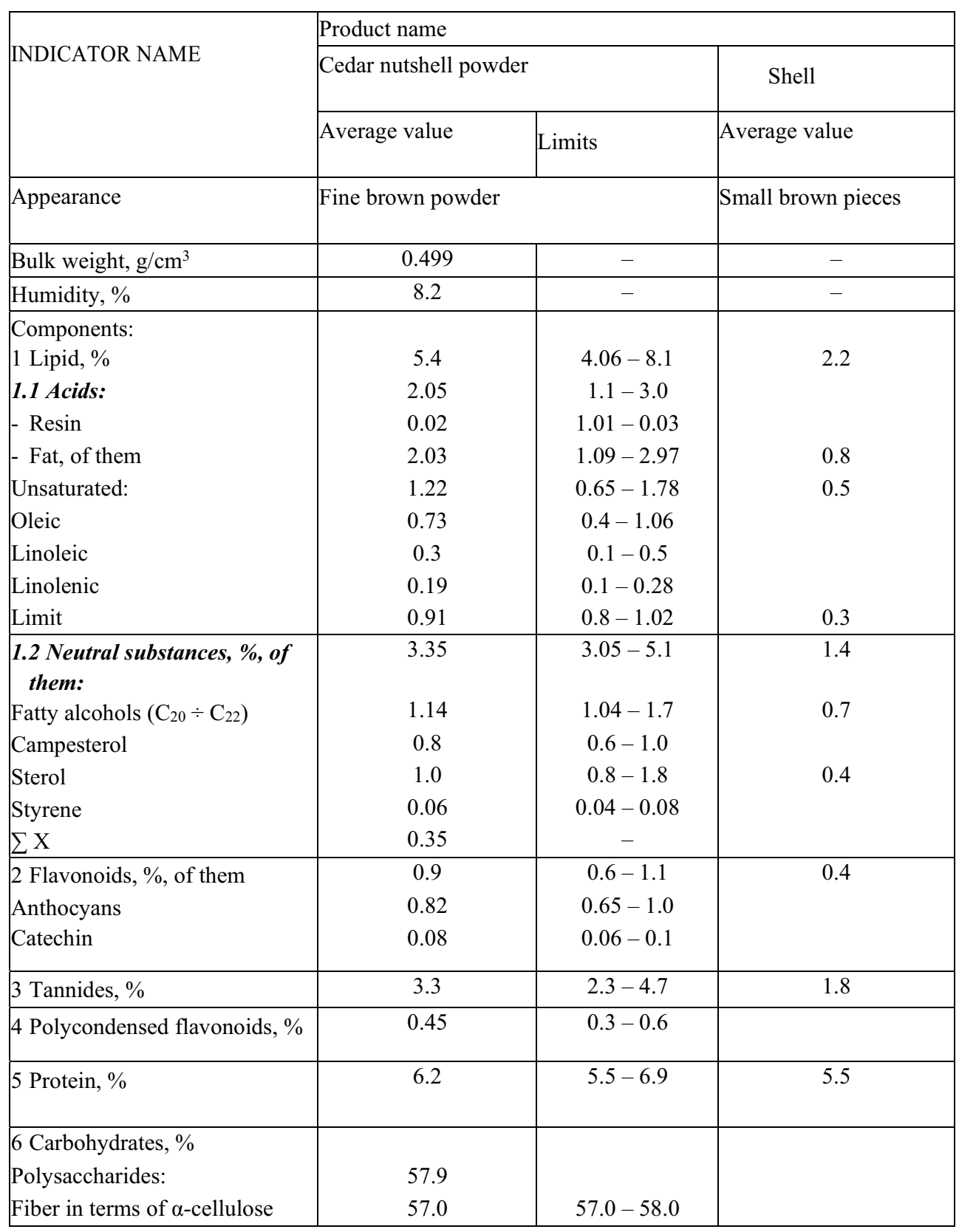




\begin{tabular}{|l|c|c|c|}
\hline Pectin substances & 0.9 & $0.8-1.1$ & \\
Monosaccharides, \% & 2.8 & $2.1-3.6$ & \\
\hline 7 Vitamins, mg/\% A (carotene) & & $0.65-1.78$ & \\
C (ascorbic acid) E (tocopherols) & Traces Traces Traces & $0.03-0.05$ & \\
F (unsaturated fatty acids) P & 1.22 & & \\
& 0.04 & & \\
\hline 8 Sum of micro- and & 1.21 & $1.16-1.26$ & \\
macronutrients, \% & & & \\
\hline
\end{tabular}

The obtained data showed a predominant increase in the content of substances due to the opening of particles, increasing their surface and biological activation during the application of grinding technology.

Currently, research is underway on the production and use of powder concentrates from agricultural waste, such as eggshells, tree bark, humus, seeds and fruit and vegetable cake. This direction is very promising both in the field of new products engineering, and in the formation of the principles of production localization.

\section{Conclusions}

1. Powdered concentrates from various types of mineral and organic raw materials were obtained under laboratory and production conditions using the developed technology. The research has proved that such concentrates have scientific, technical and applied potential in the following applications:

- $\quad$ agro-complex and agriculture (feed additives, fertilizers, processing, etc.);

- industrial production (natural dyes, waste processing, processing of raw materials, etc.);

- food additives, molecular cuisine and functional nutrition.

2. The main groups of biologically active substances that cause the action of Kedrokorm are carbohydrates, which make up $68.4 \mathrm{~g}$, as well as potassium in the amount of $670.0 \mathrm{mg}$ and phosphorus $-300.0 \mathrm{mg}$ per $100 \mathrm{~g}$ of the product. Feeding of a feed additive provides an energy-sorbent, detoxifying effect, regulates protein and mineral metabolism, and stimulates the immune system of farm animals.

3. Production tests of Kedrokorm for the treatment of gastrointestinal diseases in calves were conducted on the basis of the educational and experimental farm of the St. Petersburg State Agrarian University. The preventive effectiveness of the feed additive is $80 \%$ for the experimental groups of animals against $40 \%$ for the control group.

4. The inclusion of the feed additive Kedrokorm in the diet of lactating cows in the amount of $40 \ldots 60$ grams per day has a positive effect on the body's metabolic processes and contributes to an increase in productivity by $1 \ldots 1.51$, while increasing the fat content of milk and improving its taste.

The feed supplement added to the diet of chickens has a significant impact on their growth, development, and also improves the quality of egg products.

Feeding of the supplement to chickens for $10 \ldots 30$ days, starting from $3 \ldots 6$ days of age at a dose of $0.3 \ldots 1.3 \mathrm{~g} / \mathrm{kg}$ of body weight once a day, prevents gastrointestinal diseases, normalizes metabolic processes, accelerates their growth and development by $4 . . .7 \%$ compared to the control.

5. It is established that a promising direction in the implementation of nano shredding technologies at agricultural enterprises is the processing of waste, such as eggshells, humus, vegetable and fruit cake.

The conducted research and the results obtained allow to state that this technology 
provides high-quality powdered concentrates from cheap raw materials, as well as during recycling and reactivation. It is applicable in waste-free production, has a positive impact on the environment, is a locomotive of biological purification and a powerful tool for processing useful but unused ingredients of the agro-industrial complex as a whole.

\section{References}

1. A.G. Kulikov, A.E. Blagov, N.V. Marchenkov, V.A. Lomonov, A.V. Vinogradov, Yu. V. Pisarevsky, M.V. Kovalchuk, JETP Letters, 107(10), 646-650 (2018)

2. K.M. Boyko, V.O. Popov, M.V. Kovalchuk. Reviews, 84(8) 853-859 (2015)

3. M.A. Kerimov, Proceedings of the Saint Petersburg State Agrarian University, 1(58), 166-171 (2020)

4. Kinta Yasuyoshi, Hatta Tamao. Journal American Oil Chemistry Society, 84(2), $107-$ 115 (2007)

5. M.I. Alymov, P.Yu. Gulyaev, S.V. Semichev, Bulletin of the YuSU, 4(55), 7-16 (2019)

6. P.B. Intipunya, Chiang Mai University, Thailand, R.Bhandari, "Chemical Deterioration and Physical Instability of Food and Beverages", The University of Queensland, Australia

2010https://www.sciencedirect.com/science/article/pii/B9781845694951500228

7. C. GaianiJ.BurgainJ.Scher, "Surface composition of food powders", Université de Lorraine, France, 2013,https://www.sciencedirect.com/science/article/pii/B9780857095138500145

8. B. Cuq, C. Gaiani, C. Turchiuli, L. Galet, J. Scher, R. Jeantet, S. Mandato, J. Petit, I. Murrieta-Pazos, A. Barkouti, P. Schuck, E. Rondet, M. Delalonde, E. Dumoulin, G. Delaplace, T. Ruiz, Montpellier SupAgro, UMR 1208 IATE, Montpellier, France, Powder Agglomeration Engineering, France 2013,https:/www.sciencedirect.com/science/article/pii/B9780124105409000028

9. Alessio Cappelli, "Improving roller milling technology using the break, sizing, and reduction systems for flour differentiation" (University of Florence, 2020)

10. Dr. Ertan Ermiş, "Food Powders Properties and Characterization" (Istanbul Sabahattin Zaim University, Turkey, 2020)

11. Bhandari Bhesh, H. Yrjo, Food materials science and engineering. Chichester (United Kingdom: Wiley - Blackwell, 2012) doi: 10.1002/9781118373903

12. Walter Peggy, Comillon Paul, Journal American Oil Chemistry Society, 78(9), 927$932(2001)$ 